\title{
The Trichoptera fauna of the Oja River (La Rioja, Spain)
}

\author{
MARÍA VALLADOLID ${ }^{1 *}$, JUAN JOSÉ MARTÍNEZ-BASTIDA ${ }^{2,3} \&$ MERCEDES ARAUZO $^{2,4}$ \\ ${ }^{1}$ Department of Biodiversity and Evolutionary Biology, National Museum of Natural History (CSIC), c/ José Gutiérrez Abascal, 2. \\ 28006 Madrid, Spain \\ E-mail: marval@mncn.csic.es \\ ${ }^{2}$ Department of Environmental Contamination, Institute for Agricultural Sciences (ICA), Center for Environmental Sciences (CSIC), \\ c/ Serrano 115 dpdo., 28006 Madrid, Spain \\ E-mail: ${ }^{3}$ Martinez.Bastida@ccma.csic.es, ${ }^{4}$ mercedes@ccma.csic.es \\ (*) corresponding author
}

\begin{abstract}
The Oja River (La Rioja, Spain), belonging to the Ebro River Basin (NE Spain), encloses 3 different fluvial types (Mediterranean siliceous mountain, Mediterranean calcareous mountain and Humid calcareous mountain rivers) that give rise to a great diversity in the fauna of aquatic macroinvertebrates.

During the years 2003-2009 benthic macroinvertebrates (aquatic stages and adults) were sampled in 7 sites along the river ( 3 in siliceous stretches, 1 in humid calcareous stretch and 3 in calcareous stretches) in different seasons.

We have found 54 Trichoptera taxa, belonging to 31 genera and 16 families. Hydropsychidae (10 species), Limnephilidae (7 species) and Rhyacophilidae ( 7 species) were the dominant families. Most of the species have wide European distribution (50\%), with the Iberian endemic species (22\%) and Central and Western European species (18\%) being the 2nd and 3rd groups in importance.

The presence of some relict species in headwaters [Thremma gallicum McLachlan, Larcasia partita Navas and Odontocerum albicorne (Scopoli)] support the inclusion of this geographical area (Sierra de la Demanda, Iberian System Mountains) in the list of European pre-Pleistocene refuges for the Trichoptera fauna.
\end{abstract}

Key words: benthic macroinvertebrates, caddisfly, endemic species, relict species

\section{Introduction}

The aquatic entomofauna of La Rioja (Spain) was studied for the first time in the early 20th century by Navás (1914; 1917a, b), mainly in the mountainous areas of Ortigosa, Valvanera and Sierra de Cameros (Iregua and Najerilla Rivers). García de Jalon (1982a, b, c) in his papers about Spanish Trichoptera provides information about Trichoptera from Iregua and Nájera Rivers. On the other hand, there is scarce information of the aquatic fauna of Oja River: one paper about Coleoptera of the Iberian System that includes Oja River (Valladares et al. 2000), and 3 recent papers with preliminary results on aquatic macroinvertebrates (Martínez-Bastida et al. 2006; Valladolid et al. 2006, 2007).

Knowledge of Spanish Trichoptera has increased in recent years, not only with the description of larvae or new species (Vieira-Lanero 2000) and with the preparation of specific keys (ZamoraMuñoz et al. 1992, 1995; Vieira-Lanero 2000; Ruiz et al. 2004) but also with the publication of faunistic data (González et al. 1992, Ruiz et al. 2001, González 2003, Bonada et al. 2004). We want 
to improve this knowledge with information about the caddisfly fauna from Oja River, an almost unknown river of La Rioja that gives its name to the Community.
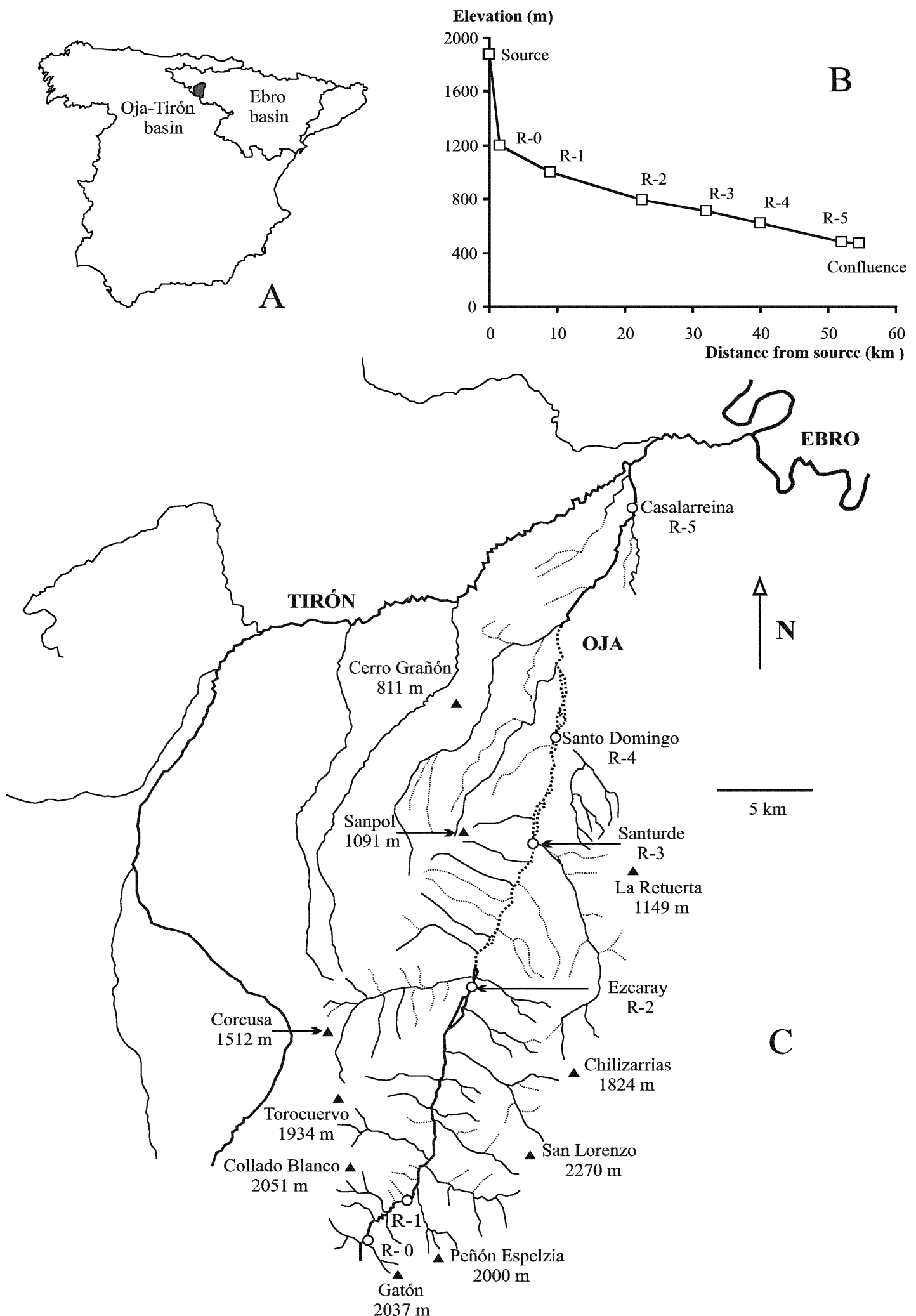

FIGURE 1. Location of Oja River. A) Situation of the Oja-Tirón basin into the Ebro basin. B) Longitudinal profile of Oja River. C) Map of the Oja-Tirón basin, with sampling points. R-0: Eagle's dam (Oja River and tributary), R-1: Oja river upstream Posadas. 


\section{Study area}

The study was carried out along the Oja River (La Rioja, Spain) (Fig.1). Originating by the union of several creeks (from 1800 to 1500 m a.s.1.) fed with snowmelt, the river is in the Sierra de la Demanda (Iberian System Mountains) and goes through $54.5 \mathrm{~km}$ in a northerly direction before reaching the Tirón River, a right tributary of Ebro River (NE Spain). It is entirely located in the High Rioja district and, except for the headwaters, the river flows through a wide alluvial plain that is devoted mainly to intensive agriculture (crop rotation in humid Mediterranean climate). The river is characterized by extreme flow fluctuations during the year, with middle and low stretches dry during several months, due mainly to the high porosity of the aquifer and its exploitation for agriculture. On the other hand, the lowest stretch of the river works as the drainage area of the underlying alluvial aquifer, keeping running water even in the most severe periods of drought. According to the European Water Framework Directive, the Confederación Hidrográfica del Ebro (CHE: River Ebro Water Authority) divides the Oja River in 3 different fluvial types: a) siliceous Mediterranean mountain river, in the headwaters, with a Paleozoic origin; b) humid calcareous mountain river, around Ezcaray, over Mesozoic units and c) calcareous Mediterranean mountain river, downstream of Ezcaray, in Cenozoic areas (Tertiary and Quaternary materials) that enclose the alluvial aquifer. In type a) we sampled points R-0, R-0-T and R-1 (1200-1000 m a.s.1.), in type b) we sampled point R-2 (Ezcaray, $790 \mathrm{~m}$ a.s.1.) and in type c) we sampled points R-3 to R-5 (711 to $480 \mathrm{~m}$ a.s.1.). The geographical information is summarized in Table 1.

TABLE 1. Sampling sites. Point: reference number, Location: nearest locality. * Sampling points added in 2005. UTM coordinates have been calculated from the Map Number 21-11 (240), Ezcaray (Spanish Military Cartography, Scale 1: 50.000, L Series, 1989).

\begin{tabular}{|c|c|c|c|}
\hline Point & Location & UTM coordinates & Altitude (m) \\
\hline $\mathrm{R}-0-\mathrm{T}$ & Eagle's dam, tributary & 30T $4939004673000 *$ & $1200 \mathrm{~m}^{*}$ \\
\hline $\mathrm{R}-0$ & Eagle's dam, Oja River & 30T $4939004673000 *$ & $1200 \mathrm{~m}^{*}$ \\
\hline $\mathrm{R}-1$ & Posadas & 30T 4943004687373 & $1000 \mathrm{~m}$ \\
\hline $\mathrm{R}-2$ & Ezcaray & 30T 4993414687339 & $790 \mathrm{~m}$ \\
\hline $\mathrm{R}-3$ & Santurde & 30T 5032894699294 & $711 \mathrm{~m}$ \\
\hline $\mathrm{R}-4$ & Santo Domingo de la Calzada & 30T 5033234699202 & $616 \mathrm{~m}$ \\
\hline $\mathrm{R}-5$ & Casalarreina & 30T 5070694708340 & $480 \mathrm{~m}$ \\
\hline
\end{tabular}

\section{Material and methods}

During 2003-2004, a variable number (6-12) of seasonal, quantitative samples of macroinvertebrates were taken in 5 selected sites (from R-1 to R-5) in May, August, November 2003 and February 2004. In 2005, upstream of R-1, two sites were included: R-0 in Oja River and R-0-T in a tributary of Oja River [see Table 1 and Valladolid et al. (2007) for additional information]. Additional qualitative samples were taken in 2004 (R-1 in June, R-5 in November), 2005 (R-5 in March; R-0 and R-0-T in May; R-1 in June; R-0, R-0-T and R-1 in August), 2006 (R-1 and R-5 in June), 2007 (R-1 and R-5 in June), 2008 (R-1, R-2, R-4 and R-5 in May and June; R-1, R-2 and R-5 in August and September) and 2009 (R-1, R-2 and R-5 in June, July, August and September) .

Invertebrates were collected with a standard Surber sampler of $30 \times 30 \mathrm{~cm}$ and $250 \mu \mathrm{m}$ mesh net and drift samples were collected during $30 \mathrm{~min}$. with a drift net of $30 \mathrm{x} 30 \mathrm{~cm}$ square mouth and 250 $\mu \mathrm{m}$ mesh net. Samples were fixed in the field with formalin $10 \%$ buffered with $0.9 \% \mathrm{NaCl}$. Adults 
were collected with light trap and sweepnet in R-1 and R-5 (2008) and in R-1, R-2 and R-5 (2009). Samples were fixed in the field with $70 \%$ ethanol.

In the laboratory the different taxa were sorted under a dissecting microscope and preserved in $70 \%$ ethanol. The identification of caddisflies was made using available literature: general books (Tachet 2003) and specific keys and descriptions of larvae and adults (Zamora-Muñoz et al. 1995, Waringer \& Graf 1997, Vieira-Lanero 2000, Malicky 2004, Neu \& Tobias 2006). Spanish and European experts checked doubtful determinations of certain larvae. The Iberian distribution of species is based on the works of González et al. (1992) and Vieira-Lanero (2000) and the correct nomenclature and European distribution were checked in the web pages of Fauna Europaea (Barnard \& Malicky 2004) and of Trichoptera World Checklist (Morse 2006).

\section{Results}

\section{Trichoptera species}

A total of 7151 individuals (4853 larvae, 267 males, 503 females and 1528 pupae of different levels of maturity) were collected (Table 2). We have identified 54 taxa (28 with larvae \& adult stages, 21 with larvae stages and 5 with adult stages), belonging to 16 families (76\% of those present in the Iberian Peninsula. The best represented families are Hydropsychidae with 10 species [Hydropsyche ambigua Schmid, H. angustipennis (Curtis), H. bulbifera McLachlan, H. dinarica MarinkovicGospodnetic, H. exocellata Dufour, H. incognita Pitsch, H. gr. instabilis (Curtis), H. lobata McLachlan, H. pellucidula (Curtis) and H. siltalai Doehler]; Limnephilidae with 7 species [Allogamus laureatus (Navas), A. ligonifer (McLachlan), Chaetopteryx sp., Halesus digitatus (Paula Schrank), H. radiatus (Curtis), Limnephilus guadarramicus Schmid and Potamophylax latipennis (Curtis)] and Rhyacophilidae with 7 species [Rhyacophila fasciata cf. denticulata McLachlan, $R$. intermedia McLachlan, $R$. meridionalis E. Pictet, $R$. obliterata McLachlan, $R$. occidentalis McLachlan, $R$. terpsichore Malicky and $R$. tristis F.J. Pictet].

TABLE 2. List of caddis species collected. Cites: n.c.: new cite for La Rioja, 1: García de Jalón (1982 b), 2: García de Jalón (1982 c), 3: García de Jalón (unpublished), 4: Navás (1908), 5: Navás (1914), 6: Navás (1916), 7: Navás (1918), 8: Navás (1920), 9: Navás (1922), 10: Schmid (1949), 11: Valladolid et al. (2006), 12: Valladolid et al. (2007). ED: European distribution. EU: Europe, WE: West Europe, CWE: Central and Western Europe, EWE: Eastern and Western Europe, PAL: Palaearctic, IP: Iberian Peninsula. ID: Iberian distribution. N: North basins, NC: North and Central basins, NE: Northeastern basins, NWC: Northwest and Central basins A: widespread. Specimens. L: larvae, P: mature \& immature pupae $\left({ }^{1}\right.$ : immature pupae, ${ }^{2}$ : male \& female pupae), M: adult males, F: adult females. Flight: months with adults. ${ }^{3}$ : possible Wormaldia corvina.

\begin{tabular}{|c|c|c|c|c|c|}
\hline Species & Cites & ED & ID & Specimens & Flight \\
\hline Rhyacophila fasciata cf. denticulata Mc Lachlan, 1879 & n.c. & IP & $\mathrm{NE}$ & $8 \mathrm{~L}+17 \mathrm{P}+7 M+7 F$ & VI-IX \\
\hline Rhyacophila meridionalis E. Pictet, 1865 & 1 & WE & A & $35 \mathrm{~L}+46 \mathrm{P}+\mathbf{6} M+5 F$ & VI-IX \\
\hline Rhyacophila obliterata McLachlan, 1863 & 1,11 & EU & $\mathrm{NC}$ & $27 \mathrm{~L}+2 \mathrm{P}$ & \\
\hline Rhyacophila occidentalis McLachlan, 1879 & $1,4,8$ & WE & A & $40 \mathrm{~L}+46 \mathrm{P}+8 \boldsymbol{M}+\mathbf{4 F}$ & VII-IX \\
\hline Rhyacophila intermedia McLachlan, 1868 & n.c. & CWE & A & $4 \mathrm{~L}$ & \\
\hline Rhyacophila terpsichore Malicky, 1976 (“1975”) & 3 & IP & $\mathrm{NC}$ & $3 \mathrm{~L}+2 \mathrm{P}$ & \\
\hline Rhyacophila tristis F.J. Pictet, 1834 & 3 & EU & $\mathrm{NC}$ & $8 \mathrm{~L}$ & \\
\hline Glossosoma privatum McLachlan, 1884 & 9,10 & IP & A & $115 \mathrm{~L}+95 \mathrm{P}+5 M$ & VII-IX \\
\hline Agapetus delicatulus McLachlan, 1884 & n.c. & CWE & A & $3 M+25 F$ & VII \\
\hline Synagapetus sp. & n.c & & & $2 \mathrm{~L}$ & \\
\hline Oxyethira sp. & n.c. & & & $4 F$ & VII-VIII \\
\hline
\end{tabular}




\begin{tabular}{|c|c|c|c|c|c|}
\hline Species & Cites & ED & ID & Specimens & Flight \\
\hline Hydroptila sp. & & & & $637 \mathrm{~L}+51 \mathrm{P}^{1}$ & \\
\hline Hydroptila vectis Curtis, 1834 & n.c. & $\mathrm{EU}$ & A & $61 \mathrm{P}^{2}+15 M+61 F$ & VI-IX \\
\hline Hydroptila sparsa Curtis, 1834 & n.c. & EU & $\mathrm{NC}$ & $1 M+2 F$ & IX \\
\hline Hydroptila gr. sparsa & n.c & & & $4 F$ & VII-IX \\
\hline Agraylea sexmaculata Curtis, 1834 & n.c. & $\mathrm{EU}$ & A & $1 M$ & IX \\
\hline Philopotamus montanus (Donovan, 1813) & $3,5,9$ & EU & A & $7 \mathrm{~L}+3 \mathrm{P}+38 M+6 F$ & VI-IX \\
\hline Wormaldia corvina (McLachlan, 1884) & n.c. & IP & NWC & $7 \mathrm{~L}+1 \mathrm{P}+\mathbf{1 4 M}$ & VI-VIII \\
\hline Wormaldia sp. ${ }^{3}$ & & & & $1 F$ & VII \\
\hline $\begin{array}{l}\text { Hydropsyche ambigua (Schmid in Schmid \& } \\
\text { Botosaneanu, 1973) }\end{array}$ & 12 & IP & $\mathrm{NC}$ & $100 \mathrm{~L}+63 \mathrm{P}+21 M+55 F$ & VII-IX \\
\hline Hydropsyche gr. instabilis & 12 & & & $72 \mathrm{~L}+27 \mathrm{P}+1 M$ & VI \\
\hline Hydropsyche siltalai Doehler, 1963 & $1,11,12$ & $\mathrm{EU}$ & A & $390 \mathrm{~L}+64 \mathrm{P}+14 M+65 F$ & VI-IX \\
\hline Hydropsyche angustipennis (Curtis, 1834) & 12 & EU & & $42 \mathrm{~L}$ & \\
\hline Hydropsyche bulbifera McLachlan, 1878 & 12 & $\mathrm{EU}$ & A & $69 \mathrm{~L}$ & \\
\hline Hydropsyche exocellata Dufour, 1841 & 12 & CWE & A & $585 \mathrm{~L}+31 \mathrm{P}+39 M+107 F$ & VI-IX \\
\hline Hydropsyche dinarica Marinkovic-Gospodnetic, 1979 & 12 & $\mathrm{EU}$ & A & $29 \mathrm{~L}+22 \mathrm{P}+1 M+4 \mathrm{~F}$ & VII-IX \\
\hline Hydropsyche incognita Pitsch, 1993 & 12 & $\mathrm{EU}$ & A & $177 \mathrm{~L}+13 \mathrm{P}+11 M+67 F$ & VI-IX \\
\hline Hydropsyche lobata McLachlan, 1884 & 11,12 & IP & A & $9 \mathrm{~L}$ & \\
\hline Hydropsyche pellucidula (Curtis, 1834) & 1,4 & $\mathrm{EU}$ & A & $24 \mathrm{~L}+3 \mathrm{P}+2 M+10 F$ & VI-IX \\
\hline Plectrocnemia conspersa (Curtis, 1834) & n.c. & $\mathrm{EU}$ & $\mathrm{NC}$ & $25 \mathrm{~L}+5 M+1 F$ & VI-IX \\
\hline Polycentropus flavomaculatus (Pictet, 1834) & 2 & EU & A & $610 \mathrm{~L}+34 \mathrm{P}+6 M+13 F$ & VI-IX \\
\hline Polycentropus kingi McLachlan, 1881 & 2 & CWE & A & $12 \mathrm{~L}+26 \mathrm{P}+12 M+5 F$ & VII-IX \\
\hline Lype sp. & n.c & & & $2 \mathrm{~L}$ & \\
\hline Psychomyia ctenophora McLachlan, 1884 & n.c. & IP & $\mathrm{NC}$ & $6 \mathrm{~L}+1 M+1 F$ & VIII-IX \\
\hline Psychomyia pusilla (Fabricius, 1781) & 2,11 & $\mathrm{EU}$ & A & $3 \mathrm{~L}+1 \mathrm{P}+\mathbf{3 F}$ & VI-VII \\
\hline Tinodes assimilis McLachlan, 1885 & 9 & CWE & A & $2 \mathrm{~L}+1 M$ & VI \\
\hline Micrasema longulum McLachlan, 1876 & 3,11 & CWE & A & $5 \mathrm{~L}+35 \mathrm{P}$ & \\
\hline Micrasema minimum McLachlan, 1876 & 11 & EU & $\mathrm{NC}$ & $102 \mathrm{~L}+500 \mathrm{P}$ & \\
\hline Micrasema moestum (Hagen, 1868) & n.c & WE & A & $2 \mathrm{~L}$ & \\
\hline Lepidostoma hirtum (Fabricius, 1775) & $2,5,8$ & $\mathrm{EU}$ & A & $10 \mathrm{~L}+1 \mathrm{P}+1 M+1 F$ & VI-VII \\
\hline Limnephilus guadarramicus Schmid, 1955 & n.c. & IP & NWC & $4 \mathrm{~L}$ & \\
\hline Potamophylax latipennis (Curtis, 1834) & 2 & EU & A & $53 \mathrm{~L}+94 \mathrm{P}+36 M+12 F$ & VIII-IX \\
\hline Halesus digitatus (Paula Schrank, 1781) & n.c. & EU & $\mathrm{NE}$ & $7 \mathrm{~L}$ & \\
\hline Halesus radiatus (Curtis, 1834) & n.c. & $\mathrm{EU}$ & $\mathrm{NC}$ & $2 \mathrm{~L}$ & \\
\hline Allogamus laureatus (Navas, 1918) & n.c. & IP & $\mathrm{NC}$ & $8 \mathrm{~L}$ & \\
\hline Allogamus ligonifer (McLachlan, 1876) & 2 & CWE & A & $50 \mathrm{~L}+3 M+4 F$ & IX \\
\hline Chaetopteryx sp. & & & & $27 \mathrm{~L}$ & \\
\hline Thremma gallicum McLachlan, 1880 & n.c. & CWE & $\mathrm{NC}$ & $17 \mathrm{~L}+23 \mathrm{P}$ & \\
\hline Larcasia partita Navas, 1917 & 2 & IP & $\mathrm{NC}$ & $1042 \mathrm{~L}+135 \mathrm{P}+5 \mathbf{M}+20 F$ & VI-VIII \\
\hline Silo graellsii E. Pictet, 1865 & $5,6,7,8,10$ & EWE & $\mathrm{NC}$ & $2 \mathrm{~L}+2 \mathrm{P}$ & \\
\hline Adicella reducta (McLachlan, 1865) & 9 & EU & A & $3 \mathrm{~L}+\mathbf{1 M}$ & VII \\
\hline Ceraclea dissimilis (Stephens, 1836) & n.c. & $\mathrm{EU}$ & $\mathrm{NC}$ & $1 \mathrm{~L}+2 M+6 F$ & VI \\
\hline Mystacides azureus (Linnaeus, 1761) & n.c. & PAL & A & $6 \mathrm{~L}$ & \\
\hline $\begin{array}{l}\text { Sericostoma personatum (Spence in Kirby \& Spence, } \\
\text { 1826) }\end{array}$ & n.c. & EU & $\mathrm{NE}$ & $322 \mathrm{~L}+126 \mathrm{P}+4 M+8 F$ & VII-VIII \\
\hline Beraea terrai Malicky, 1975 & n.c. & IP & NWC & $79 \mathrm{~L}+2 \mathrm{P}$ & \\
\hline Odontocerum albicorne (Scopoli, 1763) & $2,4,5,8,9$ & EU & $\mathrm{NC}$ & $7 \mathrm{~L}+4 \mathrm{P}+2 M+1 F$ & VII-VIII \\
\hline
\end{tabular}


Table 2 summarizes the information about Trichoptera species collected in Oja River: European distribution, Iberian distribution, number of specimens and date of capture of adults. Adults were sampled from April-May to September and first captures were in June in both years.

\section{Longitudinal distribution of taxa and river zonation}

We found the highest number of species in siliceous stretch (headwaters), with 25 and 31 species in R-0 and R-1, respectively, followed by humid calcareous stretch (R-2, $26 \mathrm{sp}$.) and calcareous stretch (24 sp. in R-5). In points R-3 and R-4 (calcareous stretch) we found only 2 and 4 species, respectively (Polycentropodidae and Hydropsychidae). The low diversity at these latter sites is probably related to the characteristics of the river at these points: a wide channel, with several arms and shallow waters that give rise to small pools in late spring and dry soon afterward, together with very little vegetation in the river bed and in the margins.

The longitudinal distribution of taxa (aquatic stages only) is shown in Table 3. We found 16 taxa located only in one of the sampling sites: Rhyacophila intermedia and R. terpsichore in R-0 (1200 $\mathrm{m})$, Allogamus laureatus and Beraea terrai Malicky in R-1 (1000 m), Synagapetus sp. and Limnephilus guadarramicus in R-2 and Rhyacophila fasciata cf. denticulata, Hydropsyche angustipennis, H. incognita, H. pellucidula, Lype sp., Psychomyia pusilla (Fabricius), Tinodes assimilis McLachlan, Micrasema moestum (Hagen), Ceraclea dissimilis (Stephens) and Mystacides azureus (L.) in R-5. Eleven taxa were found in 2 sampling sites, 18 on at least 3 and probably only 1 (Hydroptila vectis Curtis) inhabits the length of the river.

Table 3 shows different faunas related with the river stretches: upper (R-0, R-1), middle (R-2) and lower (R-5). The most different fauna lives in the lowest stretch, with the upper-middle stretches (R-0, R-1 and R-2) more related through their faunas. The highest number of taxa on site R-1 probably reflects a transition between faunas from R-0 and R-2.

\section{Biogeographical notes}

Figure 2 shows the contribution of different biogeographical groups in the caddis fauna of Oja River. Most of the species (50\%) have a European distribution, with the endemic species the 2nd group in importance $(22 \%)$ and those with a Central and West European distribution the next group in importance (18\%). One important feature of the Trichoptera fauna of Oja River is the presence of species considered relicts, such as Larcasia partita Navas, Odontocerum albicorne (Scopoli) and Thremma gallicum McLachlan, with a pre-Pleistocene origin (Giudicelli 1971, Malicky 1983, González et al. 1987).

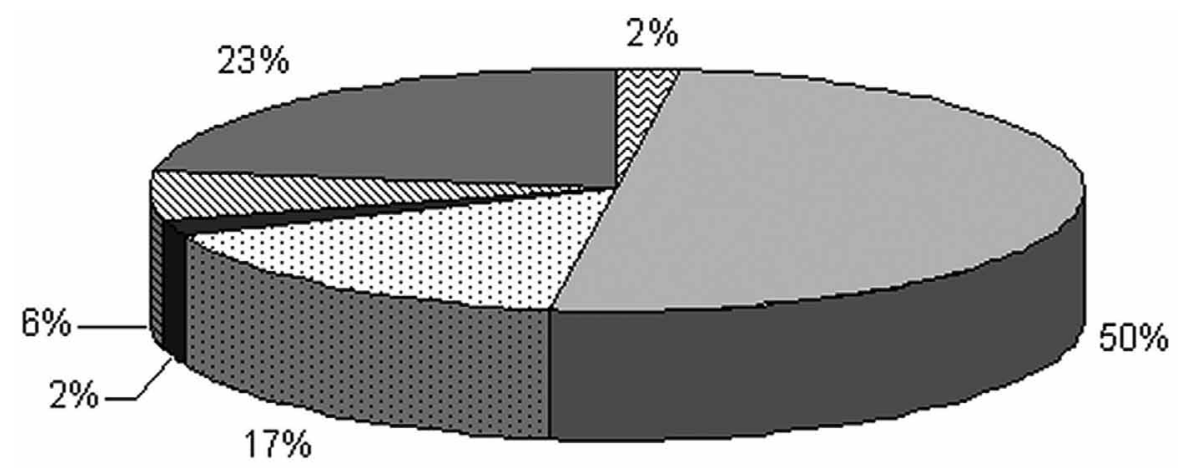

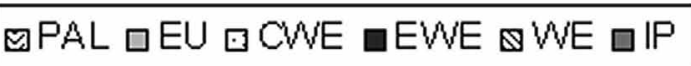

FIGURE 2. Biogeographical composition (in \%) of the Trichoptera fauna from Oja River. Number of scpecies included: 48. Biogeographical category: PAL: Palaearctic, EU: Europe, $C E W$ : Central and Western Europe, EWE: Eastern and Western Europe, WE: Western Europe, IP: Iberian Peninsula. 
TABLE 3. Altitudinal distribution of aquatic stages of Trichoptera collected. * Probably Hydroptila vectis is the dominant taxon; other species found (adults) in R-5 were H. sparsa and H. gr. sparsa. In grey: stretches with intermittent flow. SMR: Siliceous Mediterranean mountain river type, HCMR: Humid calcareous mountain river type, CMR: Calcareous Mediterranean mountain river type.

\begin{tabular}{|c|c|c|c|c|c|c|}
\hline \multirow[b]{2}{*}{ Species } & \multicolumn{2}{|c|}{ SMR } & \multirow{2}{*}{$\begin{array}{c}\text { HCMR } \\
\mathrm{R}-2 \\
790 \mathrm{~m} \\
\end{array}$} & \multicolumn{3}{|c|}{ CMR } \\
\hline & $\begin{array}{c}\mathrm{R}-0 \\
1200 \mathrm{~m}\end{array}$ & $\begin{array}{c}\mathrm{R}-1 \\
1000 \mathrm{~m}\end{array}$ & & $\begin{array}{c}\mathrm{R}-3 \\
711 \mathrm{~m} \\
\end{array}$ & $\begin{array}{c}\mathrm{R}-4 \\
616 \mathrm{~m}\end{array}$ & $\begin{array}{c}\mathrm{R}-5 \\
480 \mathrm{~m}\end{array}$ \\
\hline Rhyacophila intermedia & 1 & & & & & \\
\hline Rhyacophila terpsichore & 1 & & & & & \\
\hline Micrasema minimum & 1 & 1 & & & & \\
\hline Odontocerum albicorne & 1 & 1 & & & & \\
\hline Philopotamus montanus & 1 & 1 & & & & \\
\hline Rhyacophila occidentalis & 1 & 1 & & & & \\
\hline Rhyacophila tristis & 1 & 1 & & & & \\
\hline Silo graellsii & 1 & 1 & & & & \\
\hline Thremma gallicum & 1 & 1 & & & & \\
\hline Wormaldia corvina & 1 & 1 & & & & \\
\hline Allogaтиs laureatus & & 1 & & & & \\
\hline Beraea terrai & & 1 & & & & \\
\hline Adicella reducta & & 1 & 1 & & & \\
\hline Halesus radiatus & & 1 & 1 & & & \\
\hline Chaetopteryx sp. & 1 & 1 & 1 & & & \\
\hline Glossosoma privatum & 1 & 1 & 1 & & & \\
\hline Hydropsyche ambigua & 1 & 1 & 1 & & & \\
\hline Hydropsyche bulbifera & 1 & 1 & 1 & & & \\
\hline Hydropsyche dinarica & 1 & 1 & 1 & & & \\
\hline Hydropsyche lobata & 1 & 1 & 1 & & & \\
\hline Larcasia partita & 1 & 1 & 1 & & & \\
\hline Micrasema longulum & 1 & 1 & 1 & & & \\
\hline Polycentropus kingi & 1 & 1 & 1 & & & \\
\hline Potamophylax latipennis & 1 & 1 & 1 & & & \\
\hline Rhyacophila meridionalis & 1 & 1 & 1 & & & \\
\hline Rhyacophila obliterata & 1 & 1 & 1 & & & \\
\hline Sericostoma personatum & 1 & 1 & 1 & & & \\
\hline Synagapetus sp. & & & 1 & & & \\
\hline Limnephilus guadarramicus & & & 1 & & & \\
\hline Hydroptila sp.* & & & & & & \\
\hline Lepidostoma hirtum & 1 & 1 & 1 & & & 1 \\
\hline Allogamus ligonifer & & 1 & 1 & & & 1 \\
\hline Halesus digitatus & & 1 & 1 & & & 1 \\
\hline Psychomya ctenophora & & 1 & & & & 1 \\
\hline Hydropsyche exocellata & & & 1 & & 1 & 1 \\
\hline Hydropsyche gr. instabilis & & & 1 & & & 1 \\
\hline Hydropsyche siltalai & & & 1 & 1 & 1 & 1 \\
\hline Polycentropus flavomaculatus & & & 1 & & 1 & 1 \\
\hline Ceraclea dissimilis & & & & & & 1 \\
\hline Hydropsyche angustipennis & & & & & & 1 \\
\hline Hydropsyche incognita & & & & & & 1 \\
\hline Hydropsyche pellucidula & & & & & & 1 \\
\hline Lype sp. & & & & & & 1 \\
\hline Micrasema moestum & & & & & & 1 \\
\hline Mystacides azureus & & & & & & 1 \\
\hline Plectrocnemia conspersa & & & & & & 1 \\
\hline Psychomyia pusilla & & & & & & 1 \\
\hline Rhyacophila fasciata denticulata & & & & & & 1 \\
\hline Tinodes assimilis & & & & & & 1 \\
\hline
\end{tabular}


Figure 3 shows the importance of each biogeographical group in the different sampling points. We can see that the number of species with European distribution increases downstream, while the endemic species decrease. In the headwaters (R-0, R-0-T and R-1), we can see the only species with distribution in Eastern-Western Europe (Silo graellsii E. Pictet), while in the lowest point (R-5) we found the only species with a Palaearctic distribution (Mystacides azureus).

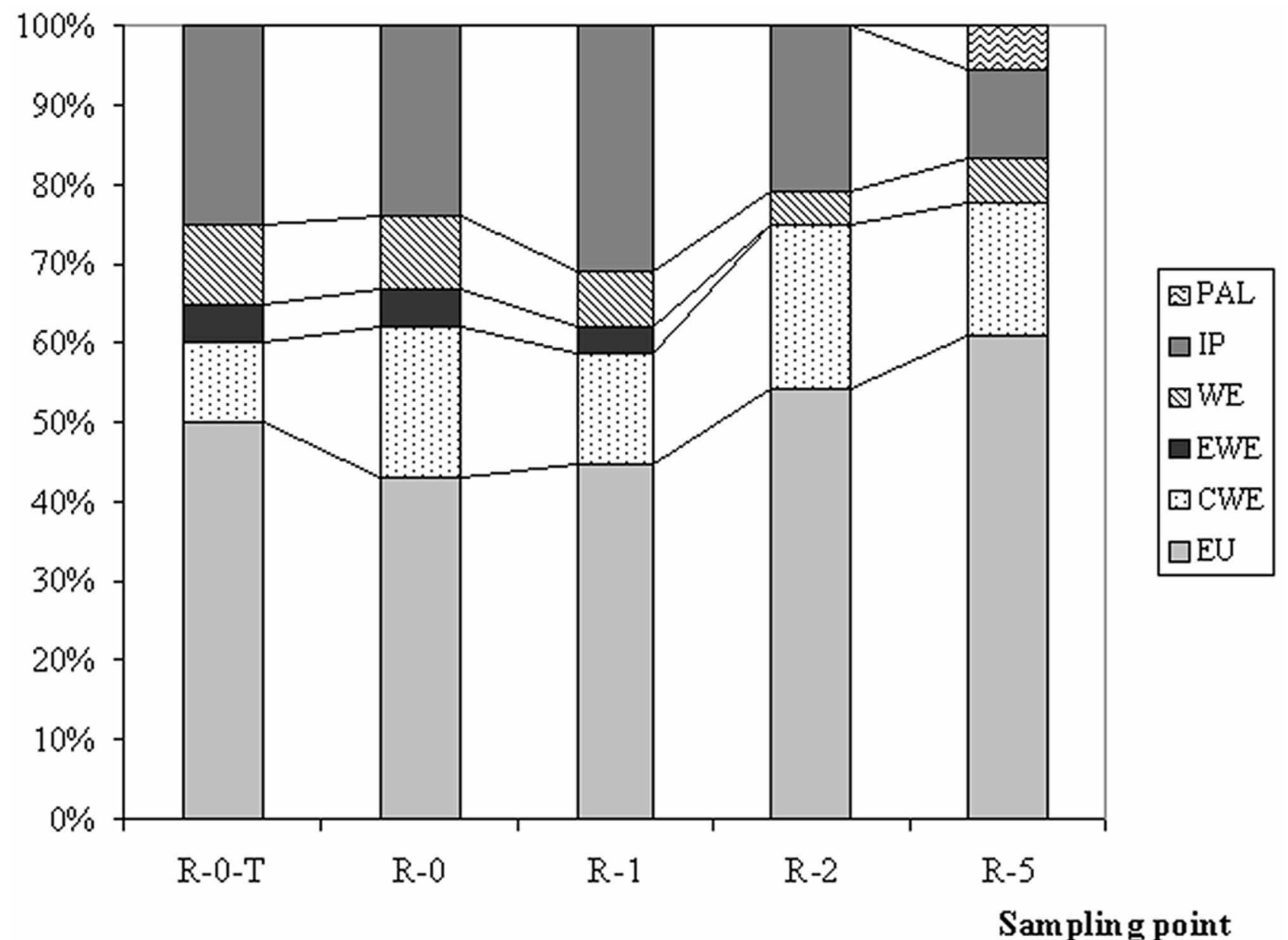

FIGURE 3. Contribution of the different biogeographical groups to the caddis fauna of each sampling point. Biogeographical category: PAL: Palaearctic, EU: Europe, $C E W$ : Central and Western Europe, EWE: Eastern and Western Europe, WE: Western Europe, IP: Iberian Peninsula.

\section{Discussion}

The Oja River, despite its short length, holds a rich Trichoptera fauna, both in number of families (16) and in number of species (54). The mixture of environments we found (siliceous, calcareous and humid calcareous reaches), originating in various geological ages, provides the basis for the presence of different Trichoptera faunas. The river is characterized by extreme flow fluctuations during the year, including long periods of time (last spring to early autumn mainly) with middle and low stretches completely dry. This fact prevents the existence of permanent communities of aquatic insects in these areas (R-3 and R-4), reflected in their poor caddis faunas (see Table 3). On the other hand, the areas with permanent water keep stable communities throughout the year, varying their composition according to the seasonal changes (e.g., spring floods). 
About the biogeographical distribution of species, Malicky (1983) proposed a new biome type for the caddisflies living in mountain streams, the dinodal, whose ecological characteristics are based in the combination of 4 elements: running turbulent water, relatively step slope, hard bottom and high water velocity. In Europe, most of the species of dinodal fauna could have originated in the mountainous regions of Central Europe, decreasing in number of species towards the North or the South. The changes in the European territory along the different geological ages could have spread species along defined areas, as for example into southwestern Europe. In this group we can include the species of European distribution, belonging to a group that first spread from the Central Mountains in Europe and also those species with Western distribution, which evolved probably after this first spread, in local areas mainly in France, Spain and Portugal.

A second type of distribution could be placed in a pre-Pleistocene period (Malicky 1983) related with certain Palaeozoic mountains (Hercinic progeny) rejuvenated in a Cenozoic period (Alpine progeny). González et al. (1987) formulated the hypothesis that the rivers of the Central System in Spain (e.g., Lozoya River) have acted as a sanctuary for aquatic species, increasing the number of individual endemic species on communities. On the other hand, Giudicelli (1971) in his study of Thremma species proposed that this genus is representative of the native European fauna from the Secondary and Tertiary ages. This fact was supported by the systematic isolation of the genus from the rest of the Trichoptera, its location on the old Hercinian Mountains and its distribution along a Circum-mediterranean and Centro European area. Malicky (1983) completed this hypothesis with the addition of Thremma, Larcasia, Odontocerum and Calamoceras, and genera with one (Larcasia) or a few European species that show geographical isolation from closely related genera/species inhabiting tropical areas and that live in geologically "older" mountains and islands (e.g., Central System mountains and Pyrenees in Spain), but not in other areas that are considered "younger" geologically (e.g., Sierra Nevada in Spain). In this group we can find 3 of the 4 representative species: Larcasia, Odontocerum and Thremma.

There is a 3rd group of species with an African origin, maybe pre-Saharan relicts and with an Atlantic distribution mostly (Malicky 1983), whose distribution is probably related with some of the connections between Europe and North Africa, before the opening of the Strait of Gibraltar in the Pliocene. Ruiz et al. (2001), in their paper about the Trichoptera fauna from Los Alcornocales Natural Park (Cádiz, South Spain), found that the most abundant group was the North African species (44.7\% of which 38\% is present only on the Iberian Peninsula and in Maghreb), followed by endemics of the Iberian Peninsula (20.6\%).

We could conclude that the Trichoptera fauna of the Oja River is the result of different geological and ecological factors. The Sierra de la Demanda (northwest end of the Iberian System Mountains) in its geological history has been connected with Europe and North Africa alternatively. The extent in the distribution of some European species present on the Iberian Peninsula (e.g., Central-Western Europe, Western Europe) could be indicative of the magnitude of their capacity and facilities for spreading.

On the other hand, the isolation of the Iberian Peninsula from Europe, due to the presence in different periods of deep seas (located in the actual Ebro basin and Pyrenees), and its connection with North Africa, was probably the origin of endemic species of the Iberian Peninsula and North Africa, supported by the presence of an increasing gradient N-S of North African - Iberian species (Ruiz et al. 2001).

Finally, we could add the Sierra de la Demanda to the list of "old sanctuary mountains" of Europe, due to its geological history as well as to the presence of several relict species such as Thremma gallicum, Larcasia partita and Odontocerum albicorne. 


\section{Acknowledgements}

This research was supported by Project REN2002-02550 (Plan Nacional $I+D+I$ ) and Technological Contract UAGR-COAG / CSIC, Ref. 2003/672. The 3rd author has had a Research grant from Comunidad de Madrid. We wish to thank José Manuel González, Marcos González, Peter Neu, Bronislaw Szczesny and Carmen Zamora-Muñoz for their help with the determination of larvae, and to librarians of the National Museum of Natural History (CSIC) for their help with bibliography. We wish to thank again to Dr. Szczesny for his valuable comments that improved the manuscript. Antonio and Abel Domínguez, Juan Carlos and Yolanda Fernández helped with the collection and Ana Jesús Loyo (Txispi), owner of Casa Ugarte, provided us nice accommodation in Ojacastro (La Rioja).

\section{References}

Barnard, P. \& Malicky, H. (Eds.) (2004) Trichoptera. Fauna Europaea version 1.1. Available from http:// www.faunaeur.org (accessed 14 April 2010).

Bonada, N., Zamora-Muñoz, C., Rieradevall, M. \& Prat, N. (2004) Trichoptera (Insecta) collected in Mediterranean river basins of the Iberian Peninsula: Taxonomic remarks and notes on ecology. Graellsia, 60 (1), 41-69.

García de Jalón, D. (1982a) Contribución a la zoogeografía de los Tricópteros españoles. Shilap, Revista de Lepidopterología, 10 (37), 75-78.

García de Jalón, D. (1982b) Contribución a la zoogeografía de los Tricópteros españoles. Shilap, Revista de Lepidopterología, 10 (38), 157-165.

García De Jalón, D. (1982 c) Contribución a la zoogeografía de los Tricópteros españoles. Shilap, Revista de Lepidopterología, 10 (39), 237-244.

Giudicelli, J. (1971) Monographie du genre Thremma, Trichoptera, Thremmatidae. Annales de Limnologie, 7 (1), $125-139$.

González, M. (Ed.) (2003) El Reino Animal en la Península Ibérica y las Islas Baleares. O. Trichoptera Kirby, 1813. MNCN (CSIC). Available from http://www.fauna-iberica.mncn.csic.es/faunaib/arthropoda/insecta/ trichoptera/index.php (accessed 14 April 2010).

González, M.A., García de Jalón, D. \& Terra, L.S.W. (1987) Faunistic studies on Iberian Trichoptera: A historical survey and present state of knowledge. In: Bournaud, M. \& Tachet, H. (Eds.), Proceedings of the Fifth International Symposium on Trichoptera, Series Entomologica, 39, Dr W. Junk Publishers, Dordrecht, Boston, Lancaster, pp. 85-90.

González, M.A., Terra, L.S.W., García de Jalón, D. \& Cobo, F. (1992) Lista faunística y bibliográfica de los Tricópteros (Trichoptera) de la Península Ibérica e Islas Baleares. Asociación Española de Limnología (Ed.), Publ. No 11, 200 pp.

Malicky, H. (1983) Chorological patterns and biome types of European Trichoptera and other freshwater insects. Archiv für Hydrobiology, 96 (2), 223-244.

Malicky, H. (2004) Atlas of European Trichoptera, 2nd Edition. Springer, Dordrecht, 385 pp.

Martínez-Bastida, J.J., Arauzo, M. \& Valladolid, M. (2006) Diagnóstico de la calidad ambiental del río Oja (La Rioja, España) mediante el análisis de la comunidad de macroinvertebrados bentónicos. Limnetica, 25 (3-4), $121-132$.

Morse, J.C. (ed.) (2006) Trichoptera World Checklist. Available from http://entweb.clemson.edu/database/trichopt/ (accessed 14 April 2010).

Navás, L. (1908) Neurópteros de España y Portugal. Broteria (Serie Zoología), 7, 5-131.

Navás, L. (1914) Notas entomológicas. 7. Excursión anual de la Sociedad Aragonesa de Ciencias Naturales a 
Ortigosa y Valvanera (Logroño). 2. Boletín de la Sociedad Aragonesa de Ciencias Naturales, 13, 29-37.

Navás, L. (1916) Tricópteros nuevos de España. 2a serie. Broteria (Serie Zoología), 14, 139-146.

Navás, L. (1917 a) Tricópteros (Ins.) de España. Asociación Española para el Progreso de la Ciencia, Congreso de Sevilla, 5-16.

Navás, L. (1917 b) Neurópteros nuevos o poco conocidos (Octava serie). Memorias de la Real Academia de las Ciencias y las Artes de Barcelona, 13, 155-178.

Navás, L. (1918) Neurópteros nuevos o poco conocidos. 10ª serie. Memorias de la Real Academia de las Ciencias y las Artes de Barcelona, 14 (4), 339-366.

Navás, L. (1920) Tricópteros (Ins.) de España. Asociación Española para el Progreso de la Ciencia, Sevilla, 4 (6), 5-16.

Navás, L. (1922) Mis excursiones entomológicas durante el verano de 1921. Boletín de la Sociedad Entomológica española, 5, 107-119.

Neu, P.J. \& Tobias, W. (2006) Die Bestimmung der in Deutschland vorkommenden Hydropsychidae. Version: 03032006 (CD).

Ruiz, A., Salamanca-Ocaña, J.C. \& Ferreras-Romero, M. (2001) Fauna de tricópteros (Insecta: Trichoptera) de cursos de agua que drenan canutos del Parque Natural Los Alcornocales (sur de España). Boletín de la Asociación española de Entomología, 25 (3-4), 105-120.

Ruiz-García, A., Salamanca-Ocaña, J.C. \& Ferreras-Romero, M. (2004) The larvae of Allogamus gibraltaricus González \& Ruiz, 2001 and Allogamus mortoni (Navás, 1907) (Trichoptera, Limnephilidae), two endemic species of the Iberian Peninsula. Annales de Limnologie - International Journal of Limnology, 40 (4), 343349.

Schmid, F. (1949) Les trichoptères de la collection Navás. Eos, 25 (3/4), 305-426.

Tachet, H., Richoux, P., Bournaud, M. \& Usseglio-Polatera, P. (2003) Invertébrés d'eau douce. Systematique, Biologie, Ecologie. Centre National de la Recherche Scientifique (CNRS) Editions, Paris. 587 pp.

Valladares, L.F., Díaz, J.A. \& Garrido, J. (2000) Coleópteros acuáticos del Sistema Ibérico Septentrional (Coleoptera: Haliplidae, Gyrinidae, Dytiscidae, Hydraenidae, Helophoridae, Hydrochidae, Hydrophilidae). Boletín de la Asociación española de Entomología, 24 (3-4), 59-84.

Valladolid, M., Martínez-Bastida, J.J., Arauzo, M. \& Gutiérrez, C. (2006) Abundancia y biodiversidad de los macroinvertebrados del río Oja (La Rioja, España). Limnetica, 25 (3), 133-140.

Valladolid, M., Martínez-Bastida, J.J. \& Arauzo, M. (2007) Los Hydropsychidae (Insecta: Trichoptera) del río Oja (La Rioja, España). Limnetica, 26 (1), 199-208.

Vieira-Lanero, R. (2000) Las larvas de los Tricópteros de Galicia (Insecta: Trichoptera). Tesis Doctoral (Ph. Dissertation), Universidad de Santiago de Compostela, $611 \mathrm{pp}$.

Waringer, J.A. \& Graf, W. (1997) Atlas der österreichischen Köcherfliegenlarven: unter Einschluss der angrenzenden Gebiete. Facultas-Universitätsverlag, Wien, 286 pp.

Zamora-Muñoz, C. \& Alba-Tercedor, J. (1992). Description of the larva of Rhyacophila (Rhyacophila) nevada Schmid, 1952 and key to the species of Rhyacophila of the Iberian Peninsula (Trichoptera: Rhyacophilidae). Aquatic Insects, 14 (2), 65-71.

Zamora-Muñoz, C., Alba-Tercedor, J. \& García de Jalón, D. (1995) The larvae of the genus Hydropsyche (Hydropsychidae; Trichoptera) and key for the identification of species of the Iberian Peninsula. Bulletin de la Societé Entomologique de Suisse, 68, 189-210. 